\title{
The Impact of the Nature of Disabling Conditions on the Reasoning Process
}

\author{
K. Dieussaert, W. Schaeken and G. D'Ydevalle
}

\section{Q OpenEdition \\ 1 Journals}

\section{Electronic version}

URL: http://journals.openedition.org/cpl/153

DOI: $10.4000 / \mathrm{cpl} .153$

ISSN: $1379-6100$

\section{Publisher}

Centre PsyCLÉ

\section{Printed version}

Date of publication: 1 April 2002

\section{Electronic reference}

K. Dieussaert, W. Schaeken and G. D'Ydevalle, «The Impact of the Nature of Disabling Conditions on the Reasoning Process », Current psychology letters [Online], 2002/1, 7| 2002, Online since 04 September 2003, connection on 08 September 2020. URL : http://journals.openedition.org/cpl/153 ; DOI : https://doi.org/10.4000/cpl.153

This text was automatically generated on 8 September 2020.

(C) All rights reserved 


\section{The Impact of the Nature of Disabling Conditions on the Reasoning Process}

K. Dieussaert, W. Schaeken and G. D'Ydevalle 